\title{
Ocena skutków regulacji zawartych w rządowym projekcie ustawy o Rzeczniku Praw Podatnika'
}

Utworzenie Rzecznika Praw Podatnika ma zwiększyć poczucie bezpieczeństwa podatników w kontaktach z organami administracji skarbowej, przyczynić się do zmiany praktyki urzędniczej na bardziej przyjazną w stosunku do obywateli oraz do polepszenia jakości polskiego prawa podatkowego i ujednolicenia jego stosowania. Zdaniem autora opinii instytucja RPP nie może stanowić samoistnej gwarancji ochrony praw podatników. Rzecznik może być jedynie instytucją wspomagającą działania organów władzy ustawodawczej i wykonawczej w kształtowaniu obowiązków podatkowych oraz wykonywaniu prawa podatkowego przez organy podatkowe. Skuteczność RPP uzależniona będzie w praktyce nie tylko od jego aktywności w wykonywaniu ustawowych zadań, ale również jego relacji ustrojowych i faktycznych z ministrem właściwym do spraw finansów publicznych i organami podatkowymi.

Słowa kluczowe: ocena skutków regulacji, podatek, podatnik, projekt ustawy, rzecznik

Impact assessment of the Governmental Bill on the Ombudsman for Taxpayers: The creation of the Ombudsman for Taxpayers (OT) is supposed to cause an increase of the sense of security of taxpayers in their contacts with tax administration bodies, contribute to the change of official practice to a more citizen-friendly one and to the improvement of the quality of Polish tax law as well as to the unification of its application. In the opinion of the author, the institution of the OT cannot constitute an independent guarantee of protection of taxpayers' rights. The Ombudsman can only be an institution supporting the activities of legislative and executive authorities in shaping tax obligations and executing tax law by tax authorities. In practice, the effectiveness of the OT will depend not only on its activity in carrying out statutory tasks, but also on its political and factual relations with the minister in charge of public finances and tax authorities.

Keywords: impact assessment, tax, taxpayer, bill, ombudsman

\section{Zakres przedmiotowy ustawy}

Projektowana ustawa ustanawia nowy organ - Rzecznika Praw Podatnika (dalej: Rzecznik lub RPP), określa jego zadania, kompetencje, zasady wyboru i powołania, warunki, jakie musi spełniać kandydat na Rzecznika, przyczyny jego odwołania, długość kadencji (jej początek i koniec), zasady wyboru i powołania

1 Ocena skutków prawnych regulacji zawartej w rządowym projekcie ustawy o Rzeczniku Praw Podatnika (druk nr 3516) sporządzona 23 lipca 2019 r. na zlecenie zastępcy Szefa Kancelarii Sejmu; BAS-WASiE 1102/19. 
zastępców Rzecznika i jego przedstawicieli terenowych, warunki, jakie muszą oni spełniać, zasady finansowania działalności Rzecznika, organizację jego prac, relacje $\mathrm{z}$ innymi organami ochrony prawa - Rzecznikiem Praw Obywatelskich (RPO) i Rzecznikiem Małych i Średnich Przedsiębiorców (RMiŚP) oraz ministrem właściwym do spraw finansów publicznych (Ministrem Finansów) i organami skarbowymi.

Projektowana ustawa ma wejść w życie w terminie i na zasadach określonych w rządowym projekcie ustawy - Przepisy wprowadzające ustawę - Ordynacja podatkowa i ustawę o Rzeczniku Praw Podatnika (druk nr 3518; dalej: przepisy wprowadzające $)^{2}$; (art. 28 projektu).

Zgodnie $\mathrm{z}$ art. 1 ust. 2 przepisów wprowadzających projektowana ustawa ma wejść w życie z dniem 1 stycznia 2020 r., z wyjątkiem art. 13 ust. 1 pkt $2^{3}$ i art. 15 ust. 1 pkt $12^{4}$ projektu, które mają wejść w życie z dniem 1 stycznia 2021 r.

W projekcie uregulowano również maksymalny limit wydatków budżetu państwa przeznaczonych na wykonywanie zadań Rzecznika w latach 2020-2029 (art. 27 projektu). Limit ten ma wynieść $263,2 \mathrm{mln} \mathrm{zl}, \mathrm{w}$ tym w poszczególnych latach: 2020 r. - 25,5 mln zł, 2021 r. - 24,1 mln zł, 2022 r. - 24,6 mln zł, 2023 r. 25,2 mln zł, 2024 r. - 25,7 mln zł, 2025 r. - 26,3 mln zł, 2026 r. - 27,0 mln zł, 2027 r. - 27,6 mln zł, 2028 r. - 28,3 mln zł, i 2029 r. - 28,9 mln zł.

2 W zakresie odnoszącym się do projektowanej ustawy przepisy wprowadzające zawierają zmiany do: ustaw: z 17 czerwca 1966 r. o postępowaniu egzekucyjnym w administracji (t.j. Dz.U. 2018, poz. 1314, ze zm.), z 31 lipca 1981 r. o wynagrodzeniach osób zajmujących kierownicze stanowiska państwowe (t.j. Dz.U. 2019, poz. 152), z 15 lipca 1987 r. o Rzeczniku Praw Obywatelskich (t.j. Dz.U. 2018, poz. 2179, ze zm.), z 9 maja 1996 r. o wykonywaniu mandatu posła i senatora (t.j. Dz.U. 2018, poz. 1799), z 30 sierpnia 2002 r. - Prawo o postępowaniu przed sądami administracyjnymi (t.j. Dz.U. 2018, poz. 1302, ze zm.), z 18 października 2006 r. o ujawnianiu informacji o dokumentach organów bezpieczeństwa państwa z lat 1944-1990 oraz treści tych dokumentów (t.j. Dz.U. 2019, poz. 430, ze zm.), z 6 marca 2018 r. o Rzeczniku Małych i Średnich Przedsiębiorców (Dz.U. poz. 648); por. art. 4 pkt 8, art. 5, art. 14, art. 34, art. 59, art. 91 i art. 154 przepisów wprowadzających.

3 W art. 13 ust. 1 projektowanej ustawy określone zostały zadania Rzecznika Praw Podatnika, pkt 2 dotyczy promowania mediacji między podatnikami (płatnikami, inkasentami, następcami prawnymi, osobami trzecimi) a organami podatkowymi.

$4 \quad$ Artykuł 15 ust. 1 projektowanej ustawy zawiera katalog uprawnień Rzecznika, pkt 12 dotyczy uprawnienia do występowania do ministra właściwego do spraw finansów publicznych o uchylenie lub zmianę w niezbędnym zakresie decyzji ostatecznej, jeżeli w inny sposób nie można usunąć stanu zagrażającego szczególnie ważnemu interesowi podatnika. 


\section{Podmioty, na które oddziałuje akt}

Projekt dotyczy ${ }^{5}$ :

- bezpośrednio:

a) wszystkich podatników, płatników, inkasentów, następców prawnych, osób trzecich - ok. 25,5 mln osób fizycznych, osób prawnych i jednostek organizacyjnych niemających osobowości prawnej,

b) organów podatkowych i jednostek organizacyjnych:

- administracji rządowej (Krajowej Administracji Skarbowej) - dyrektorów izb administracji skarbowej (16), naczelników urzędów skarbowych (400), naczelników urzędów celno-skarbowych (16) i obsługujących ich jednostek organizacyjnych (izb i urzędów),

- administracji samorządowej - wójtów, burmistrzów, prezydentów miast (2477), starostów (314), marszałków województw (16) i obsługujących ich urzędów gminnych, miejskich, powiatowych oraz marszałkowskich ${ }^{6}$.

- pośrednio:

a) organizacji przedsiębiorców, samorządów zawodowych - 261 podmiotów,

b) organów ochrony prawa - Rzecznika Praw Obywatelskich i Rzecznika Małych i Średnich Przedsiębiorców,

c) sądów administracyjnych - Naczelnego Sądu Administracyjnego i wojewódzkich sądów administracyjnych,

d) Sejmu i Senatu.

\section{Celowość wprowadzenia aktu}

Jak wynika z uzasadnienia rządowego projektu, celem projektowanej regulacji jest zagwarantowanie praw podatnikom oraz zwiększenie ich poczucia bezpieczeństwa w kontaktach z organami administracji skarbowej, co ma niezwykle istotne znaczenie w przypadku regulacji prawnopodatkowych ze względu na stopień skomplikowania przepisów podatkowych, wynikający m.in. z dynamicznie zmieniajacego się otoczenia prawno-gospodarczego.

Instytucja Rzecznika w intencji projektodawców ma przede wszystkim wzmocnić pozycję podmiotów najsłabszych, czyli takich, które co do zasady nie korzystaja z kosztownych ustug wyspecjalizowanych firm doradczych i kancelarii prawnych.

5 Dane z Ministerstwa Finansów.

6 Dane z bazy jednostek samorządu terytorialnego, www.administracja.mswia.gov.pl/ adm/baza-jst/843,Samorzad-terytorialny-w-Polsce.html [dostęp 21 czerwca 2019 r.]. Według stanu na 1 stycznia 2019 r. w Polsce było 2477 gmin, w tym 1537 wiejskich, 638 miejsko-wiejskich, 302 miejskie, 314 powiatów i 16 województw. 
Działania Rzecznika mają: istotnie ograniczyć po stronie podatników niepewność obrotu i zmniejszyć ryzyko prowadzenia działalności gospodarczej, w tym zwłaszcza $w$ sektorze mikroprzedsiębiorstw, który stanowi ponad 96\% polskich firm, [przyczynić się] do zmiany praktyki urzędniczej na bardziej przyjazna $w$ stosunku do obywateli [oraz] do polepszenia jakości polskiego prawa podatkowego i ujednolicenia jego stosowania, m.in. poprzez przeglą $i$ analizę postępowań, w tym zwłaszcza sadowych, „przegranych” przez organy administracji skarbowej.

Jak podkreślono w uzasadnieniu, [c]iagły monitoring stosowania przepisów prawa podatkowego umożliwi w razie konieczności szybka reakcję ze strony RPP poprzez wystąpienie $z$ wnioskiem o podjęcie inicjatywy ustawodawczej, o wydanie interpretacji ogólnej, czy zwrócenie się o wszczęcie postępowania podatkowego lub wniesienie skargi do sądu administracyjnego.

Autorzy projektu zauważają, że: [o]chrona praw podatnika ma swój aspekt indywidualny oraz społeczny. W aspekcie indywidualnym istotne jest to, aby podatnik miał do dyspozycji środki prawne umożliwiajace precyzyjne ustalenie zakresu jego obowiązków oraz umożliwiające weryfikację prawidłowości działania organów podatkowych, a także eliminację zaistniałych ewentualnie nieprawidłowości oraz usunięcie ich skutków. W aspekcie społecznym ochrony praw podatnika chodzi o to, aby zespół instrumentów prawnych oddanych do dyspozycji podatników oraz warunki i możliwości korzystania z nich przyczyniały się do utrwalenia przekonania, że opodatkowanie przebiega według społecznie akceptowalnych regut oraz $z$ poszanowaniem praw jednostki. W konsekwencji powinno to umocnić poczucie więzi obywateli z państwem (bądź bardziej ogólnie - ze zbiorowościa społeczną) oraz przekonanie o racjonalności zachowań zgodnych z prawem podatkowym.

Uzasadniając potrzebę wprowadzenia do polskiego porządku prawnego instytucji Rzecznika Praw Podatnika, odwołano się również do statystyk sądowych (liczby skarg kierowanych do sądów administracyjnych w sprawach podatkowych i ich udziału w skargach ogółem), regulacji w innych państwach (Kanadzie, RPA, Meksyku, Australii, Gruzji, Ukrainie, niektórych stanach USA), wskazań OECD oraz polskiej „Deklaracji praw podatnika”, podpisanej w 2011 r. przez przedstawicieli nauki, sędziów oraz praktyków prawa podatkowego.

\section{Planowane środki (narzędzia i działania) realizacji celów}

Środkiem do realizacji zakładanych celów - zagwarantowania praw podatnikom oraz zwiększenie ich poczucia bezpieczeństwa w kontaktach z organami administracji skarbowej, polepszenia jakości polskiego prawa podatkowego i ujednolicenie jego stosowania - jest powołanie do życia instytucji Rzecznika Praw Podatnika.

W ocenie skutków regulacji (OSR) załączonej do projektu podkreślono, że: [j]edynie powołanie odrębnej, wyspecjalizowanej $w$ prawie podatkowym instytu- 
cji ochrony prawnej daje możliwość osiagnięcia zamierzonego celu. Nie jest możliwe wskazanie całkiem odmiennego rozwiązania alternatywnego $w$ stosunku do projektowanego aktu prawnego, które umożliwiałoby zapewnienie kompleksowej ochrony praw wszystkim podatnikom. Funkcjonujące w polskim systemie prawnym organy ochrony prawnej takie jak Rzecznik Praw Obywatelskich (dalej: RPO) i Rzecznik Małych i Średnich Przedsiębiorców (dalej: RMIŚP) nie są wystarczajace do ochrony praw podatników. Zarówno ustawowe uprawnienia RPO i RMIŚP, jak $i$ stawiane im kryteria kompetencyjne nie daja gwarancji szerokiego, skutecznego $i$ wyspecjalizowanego działania $w$ zakresie prawa podatkowego. RPO nie zawsze może interweniować w sprawach podatników, bowiem nie zawsze sa nimi obywatele (w zakresie podatku CIT czy VAT podatnikami sa najczęściej osoby prawne, które co do zasady nie podlegaja konstytucyjnej ochronie ze strony RPO). Również nie wydaje się celowe przyznanie RMIŚP kompetencji do interweniowania w sprawach podatników niebędących przedsiębiorcami, albowiem pozostawałoby to $w$ oczywistym konflikcie interesów konsumentów i przedsiębiorców - nie zawsze interpretacja poszczególnych przepisów prawa jest korzystna dla obu tych grup. Do RPP będa natomiast mogły kierować prośby o interwencje wszystkie grupy podatników $i$ tylko takie rozwiązanie daje gwarancje kompleksowej ochrony praw wszystkich podatników.

Cele projektowanej ustawy mają zostać zrealizowane przez przyznanie Rzecznikowi licznych uprawnień o charakterze proceduralnym ${ }^{7}$. Ponadto RPP będzie uprawniony do występowania do właściwego organu $\mathrm{z}$ wnioskiem o podjęcie inicjatywy ustawodawczej albo wydanie innego aktu normatywnego w sprawach podatkowych, występowania do RPO z wnioskiem o skierowanie przez RPO

7 To znaczy: występowanie o wydanie interpretacji ogólnej lub indywidualnej, objaśnień podatkowych w sprawach będących źródłem poważnych wątpliwości interpretacyjnych, z wnioskiem do Naczelnego Sądu Administracyjnego (NSA) o podjęcie uchwały mającej na celu wyjaśnienie przepisów prawnych, których stosowanie wywołało rozbieżności w orzecznictwie sądów administracyjnych, zwracanie się o wszczęcie postępowania podatkowego oraz wnoszenie skargi do sądu administracyjnego, skargi kasacyjnej do NSA, zażalenia w postępowaniu sądowoadministracyjnym, skargi o wznowienie postępowania, które zostało zakończone prawomocnym orzeczeniem sądu administracyjnego, i skargi o stwierdzenie niezgodności z prawem prawomocnego orzeczenia sądu administracyjnego, a także uczestniczenia $\mathrm{w}$ postępowaniu podatkowym i postępowaniu sądowoadministracyjnym, występowanie do właściwego organu z wnioskiem o wstrzymanie czynności egzekucyjnych oraz z wnioskiem o wstrzymanie postępowania egzekucyjnego, prowadzonych przeciwko podatnikowi na podstawie ustawy o postępowaniu egzekucyjnym w administracji, występowanie do ministra właściwego do spraw finansów publicznych o uchylenie lub zmianę w niezbędnym zakresie każdej decyzji ostatecznej, jeżeli w inny sposób nie można usunąć stanu zagrażającego szczególnie ważnemu interesowi podatnika, składanie środków zaskarżenia na podstawie przepisów Ordynacji podatkowej (art. 15 projektu). 
wniosku do Trybunału Konstytucyjnego w sprawie, o której mowa w art. 188 Konstytucji, dotyczącej praw podatnika (uprawnienia inicjujące proces legislacyjny lub zbadanie zgodności aktu normatywnego z Konstytucją, ustawą, umową międzynarodową) oraz kierowania wystąpienia do organu, w którego działalności RPP stwierdził naruszenie praw podatnika, informowania właściwych organów nadrzędnych lub organów kontroli o dostrzeżonych nieprawidłowościach w funkcjonowaniu organów podatkowych, informowania właściwych organów o dostrzeżonych barierach i utrudnieniach w zakresie wykonywania obowiązków podatkowych (uprawnienia kontrolno-interwencyjne).

\section{Ocena kosztów i korzyści}

Analiza projektowanej ustawy wskazuje, że proponowaną instytucję RPP zaliczyć należy do organów ochrony prawa. W tym zakresie funkcjonują już Rzecznik Praw Obywatelskich ${ }^{8}$ i od 3 kwietnia 2018 r. Rzecznik Małych i Średnich Przedsiębiorców ${ }^{9}$. Obok RPO i RMiŚP w polskim systemie prawnym mamy Rzecznika Finansowego $^{10}$, Rzecznika Praw Dziecka ${ }^{11}$, Rzecznika Praw Pacjenta ${ }^{12}$.

Nie zawsze ustanowienie nowego organu ochrony prawa musi prowadzić do faktycznego zwiększenia poziomu tej ochrony. Większość z przywołanych organów istnieje od wielu lat. Pomijając RPO, który jako jedyny z przywołanych organów ochrony prawa wymieniony jest w Konstytucji RP, Rzecznik Finansowy istnieje od września 2015 r., przejmując jednocześnie kompetencje Rzecznika Ubezpieczonych ${ }^{13}$, Rzecznik Praw Pacjenta od maja 2009 r., Rzecznik Praw Dziecka od 2000 r., zaś Rzecznik Małych i Średnich Przedsiębiorców od kwietnia 2018 r. Uzasadniając konieczność powołania do życia RPP, należałoby dokonać analizy i oceny, czy i jak ustanowienie wyżej wymienionych organów ochrony

8 Por. art. 208-212 Konstytucji RP oraz ustawę z 15 lipca 1987 r. o Rzeczniku Praw Obywatelskich (t.j. Dz.U. 2018, poz. 2179, ze zm.).

9 Zob. ustawę z 6 marca 2018 r. o Rzeczniku Małych i Średnich Przedsiębiorców (Dz.U. poz. 648) oraz ustawę z 6 marca 2018 r. - Przepisy wprowadzające ustawę - Prawo przedsiębiorców oraz inne ustawy dotyczące działalności gospodarczej (Dz.U. poz. 650).

10 Zob. art. 11-34 ustawy z 5 sierpnia 2015 r. o rozpatrywaniu reklamacji przez podmioty rynku finansowego i o Rzeczniku Finansowym, t.j. Dz.U. 2018, poz. 2038, ze zm.

11 Zob. ustawę z 6 stycznia 2000 r. o Rzeczniku Praw Dziecka, t.j. Dz.U. 2017, poz. 922, ze zm.

12 Zob. art. 41-58 ustawy z 6 listopada 2008 r. o prawach pacjenta i Rzeczniku Praw Pacjenta, t.j. Dz.U. 2017, poz. 1318, ze zm.

13 Zob. art. 54-62 ustawy o rozpatrywaniu reklamacji przez podmioty rynku finansowego i o Rzeczniku Finansowym oraz ustawę z 22 maja 2003 r. o nadzorze ubezpieczeniowym i emerytalnym oraz Rzeczniku Ubezpieczonych, t.j. Dz.U. 2016, poz. 477. 
prawa wpłynęło na poziom ochrony prawnej podmiotów objętych zakresem działania tych organów, a także jakie znaczenie dla poziomu tej ochrony ma pozycja ustrojowa rzecznika - usytuowanie w strukturach administracji rządowej (Rzecznik Finansowy, RMiŚP, Rzecznik Praw Pacjenta) i poza tymi strukturami (RPO, Rzecznik Praw Dziecka). W uzasadnieniu projektu brak takiej analizy. Pada za to stwierdzenie, że: [j]edynie powołanie odrębnej, wyspecjalizowanej w prawie podatkowym instytucji ochrony prawnej daje możliwość osiagnięcia zamierzonego celu, przy czym [n]ie jest możliwe wskazanie całkiem odmiennego rozwiazzania alternatywnego w stosunku do projektowanego aktu prawnego, które umożliwiałoby zapewnienie kompleksowej ochrony praw wszystkim podatnikom, bowiem [f] unkcjonujace $w$ polskim systemie prawnym organy ochrony prawnej takie jak „RPO i RMiŚP” nie sa wystarczające do ochrony praw podatników.

W tym kontekście należy zauważyć, że sama instytucja RPP, niewątpliwie potrzebna $\mathrm{w}$ polskim systemie prawnym (przede wszystkim w systemie organów ochrony prawa), nie może stanowić samoistnej gwarancji ochrony praw podatników. Rzecznik może być jedynie instytucją wspomagającą działania organów władzy ustawodawczej i wykonawczej w kształtowaniu obowiązków podatkowych w sposób wynikający z Konstytucji RP oraz wykonywaniu prawa podatkowego przez organy podatkowe zgodnie z gwarancjami wynikającymi z zasad ogólnych (praworządności, zaufania do organów podatkowych, udzielania informacji i wyjaśnień, prawdy obiektywnej, rozstrzygania wątpliwości na korzyść podatnika, przejrzystości, przekonywania, szybkości i prostoty postępowania, pisemności, dwuinstancyjności, jawności $\left.{ }^{14}\right)$. Konstatacja ta wynika z dwóch przesłanek.

- Jak zauważa w swoim orzecznictwie Trybunał Konstytucyjny (TK): daleko idace uprawnienia ustawodawcy do ksztaltowania materialnych treści prawa podatkowego sa w swoisty sposób równoważone koniecznościa respektowania przez ustawodawcę warunków formalnych, wynikających $w$ szczególności $z$ art. 2 i art. 84 Konstytucji ${ }^{15}$. W szczególności, zdaniem Trybunału, $z$ art. 84 wynika obowiązek ustawodawcy takiego stanowienia podatków, aby wynikajace z przepisów podatkowych normy prawne byly precyzyjne i nie budzily wątpliwości co do ich treści oraz aby zainteresowany znał dokładna treść $i$ wysokość ciążacych na nim obowiazków daninowych $w$ chwili zajścia zdarzeń powodujących ich powstanie ${ }^{16}$. Nie zastąpią tego już istniejące interpretacje ogólne i indywidualne, ogólne objaśnienia podatkowe dotyczące stosowania prawa podatkowego czy projektowana wiążąca informacja stawkowa ${ }^{17}$. Rzecznik Praw Podatnika będzie mógł lepiej przyczy-

14 Por. art. 120-129 ustawy z 29 sierpnia 1997 r. - Ordynacja podatkowa, t.j. Dz.U. 2018, poz. 900 , ze zm.

15 Wyrok TK z 3 lipca 2019 r., sygn. akt SK 16/17, niepubl. Por. również wyrok TK z 6 grudnia 2016 r., sygn. akt SK 7/15, OTK-A ZU 2016, poz. 100.

16 Wyrok TK z 3 lipca 2019 r., sygn. akt SK 16/17, niepubl.

17 Zob. druk sejmowy 3255/VIII kad. 
nić się do podniesienia poziomu praw podatnika, jeśli prawo podatkowe będzie w sposób jednoznaczny przesądzało zakres podmiotowy i przedmiotowy podatku, stawki podatkowe i zasady płatności, a więc kto, od czego, w jakiej wysokości, kiedy i na jakich zasadach obowiązany jest ponieść ciężar opodatkowania.

- Gwarantem należytego stosowania prawa podatkowego przez organy skarbowe powinien być w pierwszej kolejności Minister Finansów, jako minister właściwy do spraw finansów publicznych ${ }^{18}$. Dysponuje on bowiem odpowiednim instrumentarium prawnym, umożliwiającym mu nadzór i kontrolę działalności organów i jednostek organizacyjnych, w stosunku do których uzyskał uprawnienia nadzorcze na podstawie przepisów ustawowych ${ }^{19}$. Może on, zgodnie $\mathrm{z}$ art. 34a ustawy o Radzie Ministrów, w celu dostosowania do polityki ustalonej przez Radę Ministrów zasad i kierunków działania podległych lub nadzorowanych centralnych organów administracji rządowej, innych urzędów lub jednostek organizacyjnych niemających osobowości prawnej, wydawać kierownikom urzędów centralnych oraz kierownikom innych urzędów i jednostek organizacyjnych wiążące ich wytyczne i polecenia ${ }^{20}$. Minister Finansów jest też jednym z organów Krajowej Administracji Skarbowej (KAS) ${ }^{21}$ i do jego kompetencji należy koordynowanie i współdziałanie w kształtowaniu polityki państwa w zakresie zadań KAS (art. 12 u.KAS). Do zadań KAS należy m.in. zapewnienie obsługi i wsparcia podatnika i płatnika w prawidłowym wykonywaniu obowiązków podatkowych oraz obsługi i wsparcia przedsiębiorcy w prawidłowym wykonywaniu obowiązków celnych (art. 2 ust. 1 pkt 5 u.KAS), a także prowadzenie działalności informacyjnej i edukacyjnej w zakresie przepisów prawa podatkowego i celnego (art. 2 ust. 1 pkt 7 u.KAS). Zadania te realizują dyrektor Krajowej Informacji Skarbowej (art. 22 ust. 1 pkt 1-3 u.KAS), dyrektorzy izb administracji skarbowej (art. 25 ust. 1 pkt 7 u.KAS), naczelnicy urzędów skarbowych (art. 28 ust. 1 pkt 5 u.KAS). Nadzór nad działaniami organów KAS sprawuje Szef KAS (art. 14 ust. 1 pkt 1 u.KAS).

Reasumując tę część rozważań, należy podkreślić konieczność wielopłaszczyznowego spojrzenia na kwestię rozwiązania, podnoszonych w uzasadnieniu pro-

18 Zob. rozporządzenie Prezesa Rady Ministrów z 6 czerwca 2019 r. w sprawie szczegółowego zakresu działania Ministra Finansów, Dz.U. poz. 1059.

19 Zob. art. 34 ust. 2 ustawy z 8 sierpnia 1996 r. o Radzie Ministrów, t.j. Dz.U. 2012, poz. 392, ze zm.

20 Przepis ten nie ma zastosowania jedynie do organów, urzędów i jednostek wchodzących w skład zespolonej administracji rządowej, chyba że przepisy szczególne stanowią inaczej (por. art. 34a ust. 4 ustawy o Radzie Ministrów). Dyrektorzy izb administracji skarbowej, naczelnicy urzędów skarbowych oraz naczelnicy urzędów celno-skarbowych należą do organów administracji niezespolonej (por. art. 56 ust. 1 pkt 2 ustawy z 23 stycznia 2009 r. o wojewodzie i administracji rządowej w województwie, t.j. Dz.U. 2017, poz. 2234, ze zm.

21 Por. art. 11 ust. 1 pkt 1 ustawy z 16 listopada 2016 r. o Krajowej Administracji Skarbowej, t.j. Dz.U. 2019, poz. 768, ze zm.; dalej: u.KAS. 
jektowanej ustawy, problemów jakości prawa podatkowego oraz sposobu jego wykonywania przez organy podatkowe. $\mathrm{W}$ przeciwnym wypadku środki przeznaczone na funkcjonowanie RPP mogą nie przynieść oczekiwanych rezultatów, co w perspektywie kilkuletniej może negatywnie wpłynąć na wizerunek organów władzy ustawodawczej i wykonawczej.

Analiza przepisów projektowanej ustawy nasuwa pytania i wątpliwości związane z niezależnością RPP. W tym zakresie należy zauważyć kilka kwestii, wymienionych poniżej.

- Rzecznik ma być wybierany w drodze otwartego i konkurencyjnego naboru i powołany przez Prezesa Rady Ministrów (podobnie jak Rzecznik Praw Pacjen$\mathrm{ta}^{22}$ ). Jest to szczególna formuła wyłaniania kandydata na sprawowany urząd, bliższa wyborom osób zatrudnionych i piastujących funkcje $\mathrm{w}$ administracji rządowej niż pełniących funkcję organu ochrony prawa. Niemniej formuła ta wydaje się bardziej przejrzysta niż w przypadku powoływania Rzecznika Finansowego, jak i Rzecznika Małych i Średnich Przedsiębiorców, którzy wybierani są w drodze pozakonkursowej ${ }^{23}$ i powoływani są przez Prezesa Rady Ministrów. Pominąć należy wybór RPO oraz Rzecznika Praw Dziecka, którzy powoływani są przez Sejm za zgodą Senatu (zgodnie z przepisem konstytucyjnym) ${ }^{24}$.

- Ostatecznego wyboru RPP dokonywać będzie minister właściwy do spraw finansów publicznych, spośród dwóch kandydatów przedstawionych mu przez zespół (komisję) powołany przez niego do przeprowadzenia postępowania konkursowego. Przy czym projekt nie wskazuje kryteriów wyłaniania członków zespołu (komisji) konkursowego. Jedynym warunkiem, wynikającym $\mathrm{z}$ art. 6 ust. 1 projektu, jest to, aby w skład zespołu wchodziły co najmniej trzy osoby, których wiedza i doświadczenie dają rękojmię wyłonienia najlepszego kandydata na Rzecznika (art. 6 ust. 1 projektu). Ministrowi właściwemu do spraw finansów publicznych została pozostawiona swoboda $\mathrm{w}$ doborze członków zespołu (komisji). To on będzie decydował, czy kandydat na członka zespołu konkursowego odznacza się wiedzą i doświadczeniem dającymi rękojmię wyłonienia najlepszego kandydata na Rzecznika ${ }^{25}$.

22 Por. art. 44 ust. 1 ustawy o prawach pacjenta i Rzeczniku Praw Pacjenta.

23 Por. odpowiednio art. 11 ustawy o rozpatrywaniu reklamacji przez podmioty rynku finansowego i o Rzeczniku Finansowym oraz art. 3 ustawy o Rzeczniku Małych i Średnich Przedsiębiorców.

24 Por. odpowiednio art. 209 ust. 1 Konstytucji RP i art. 3 ust. 1 ustawy o Rzeczniku Praw Obywatelskich oraz art. 4 ust. 1 ustawy o Rzeczniku Praw Dziecka.

25 W tej sytuacji rozważyć można doprecyzowanie kryteriów doboru członków zespołu konkursowego i konsultacji wyboru członka np. z Krajową Izbą Doradców Podatkowych, organizacjami pracodawców, przedstawicielami nauki i sądownictwa administracyjnego oraz przedstawicielami samorządu terytorialnego. Co prawda, w rządowej ocenie skutków regulacji załączonej do projektu ustawy nie wskazano, aby projekt oddziaływał na samorządowe organy podatkowe, jednak z treści art. 1 projektu wy- 
- Zespół konkursowy ma oceniać doświadczenie i wiedzę kandydatów na Rzecznika (art. 7 ust. 1 projektu), jednak w projekcie brak jest wskazania bardziej precyzyjnych przesłanek dokonania takiej ocen ${ }^{26}$ oraz jej formuły (test, pytania zespołu/komisji, dorobek kandydata itd. $)^{27}$.

- Działalność Rzecznika finansowana ma być z części 19 budżetu państwa, której dysponentem jest minister właściwy do spraw finansów publicznych (art. 26 ust. 2 projektu), co mogłoby wskazywać, że RPP traktowany jest przez projektodawcę, jako część aparatu wykonawczego Ministra Finansów. Nota bene, sprawozdanie ze swojej działalności Rzecznik ma przedkładać Prezesowi Rady Ministrów za pośrednictwem ministra właściwego do spraw finansów publicznych, przy czym jest to sprawozdanie obowiązkowe (art. 24 ust. 1 projektu), zaś Sejmowi i Senatowi informacje wynikające $\mathrm{z}$ działalności Rzecznika nie muszą być przesyłane ${ }^{28}$, chyba że o przedstawienie informacji wystąpi Marszałek Sejmu (art. 25 ust. 2 projektu).

- Statut Biuru Rzecznika nadaje minister właściwy do spraw finansów publicznych (art. 12 ust. 11 projektu), który może również w drodze zarządzenia wskazać jednostki mu podległe lub przez niego nadzorowane, w których będą udostępnione pomieszczenia wraz z odpowiednią infrastrukturą do wykonywania zadań przez pracowników Biura Rzecznika (art. 12 ust. 12 projektu). Projekt zawiera również zobowiązanie dyrektorów izb administracji skarbowej do udostępnienia nieodpłatnie pracownikom Biura Rzecznika pomieszczeń wraz z odpowiednią

nika, że dotyczy on wszystkich podatników, a więc również podatników podatków lokalnych, które pobierane są przez organy samorządowe.

26 Art. 3 projektowanej ustawy wskazuje, że na stanowisko Rzecznika może być powołana osoba, która: 1) ma obywatelstwo polskie; 2) korzysta z pełni praw publicznych; 3) nie była skazana prawomocnym wyrokiem za umyślne przestępstwo ani umyślne przestępstwo skarbowe; 4) cieszy się nieposzlakowaną opinią oraz daje rękojmię prawidłowego i obiektywnego wykonywania powierzonych zadań; 5) wyróżnia się wysokim poziomem wiedzy w zakresie prawa podatkowego; 6) ma doświadczenie w zakresie stosowania prawa podatkowego oraz przez co najmniej 5 lat: a) wykonywała zawód doradcy podatkowego lub b) zajmowała stanowisko sędziego sądu administracyjnego, lub c) wykonywała zawód adwokata lub radcy prawnego, lub d) pełniła funkcję organu podatkowego, lub e) pozostawała na stanowisku związanym ze stosowaniem prawa podatkowego w urzędach obsługujących organy podatkowe; 7) ma co najmniej stopień naukowy doktora nauk prawnych lub ekonomicznych; 8) nie pełniła służby zawodowej ani nie pracowała w organach bezpieczeństwa państwa w rozumieniu art. 2 ust. 1 ustawy z 18 października 2006 r. o ujawnianiu informacji o dokumentach organów bezpieczeństwa państwa $\mathrm{z}$ lat 1944-1990 oraz treści tych dokumentów (Dz.U. 2019, poz. 430, 399, 447 i 534), ani nie była ich współpracownikiem.

27 Być może kwestia ta powinna być uregulowana w rozporządzeniu wykonawczym.

28 Zgodnie z art. 25 ust. 1 projektu Rzecznik może przedkładać Sejmowi i Senatowi informacje wynikające z działalności Rzecznika, a także opinie o projektach aktów normatywnych mogących wpływać na prawa podatnika. 
infrastrukturą niezbędną do realizacji zadań RPP, jeżeli zaistnieje konieczność zapewnienia efektywnej realizacji zadań Rzecznika (art. 12 ust. 10 projektu).

Rozwiązania te mogą świadczyć o umiejscowieniu RPP w strukturach rządowej administracji skarbowej, podporządkowanej ministrowi właściwemu do spraw finansów publicznych, której częścią w istocie może stać się z czasem RPP. Realizować on bowiem będzie w istotnej części zadania, które należą do kompetencji KAS (np. w sferze analiz orzecznictwa sądowego, administracyjnego, edukacji podatników, zapewnienia odpowiedniego poziomu obsługi, dbania o prawa podatnika).

Z treści art. 1 projektu wynika, że Rzecznik ma dbać o interesy wszystkich podatników (płatników, inkasentów, osoby trzecie, następców prawnych), a więc również tych, na których ciążą obowiązki w zakresie podatków i opłat lokalnych (od nieruchomości, od środków transportowych, rolnego, leśnego, opłaty miejscowej, uzdrowiskowej, od posiadania psa), pobieranych przez organy samorządowe. Tymczasem w rządowej ocenie skutków regulacji nie wskazano, aby projekt odnosił się do samorządowych organów podatkowych (zob. pkt 4 OSR), uwzględniając jedynie organy KAS i Ministra Finansów.

Wątpliwości może budzić organizacja wykonywania zadań przez Rzecznika, wynikająca z projektowanej ustawy oraz liczba i struktura etatów zakładana w rządowej ocenie skutków regulacji.

Rzecznik ma wykonywać zadania przy pomocy nie więcej niż 16 zastępców i 32 przedstawicieli terenowych oraz Biura Rzecznika (art. 12 ust. 1 projektu), przy czym zarówno zastępcy Rzecznika, jak i jego przedstawiciele terenowi będą pracownikami Biura (art. 12 ust. 5 projektu). Założono, że zostanie utworzonych 136 etatów: RPP (1), zastępcy (16), przedstawiciele terenowi (32), pracownicy terenowi do obsługi administracyjno-biurowej zastępców i przedstawicieli terenowych (32) oraz pozostali pracownicy (55) (zob. s. 7 OSR). Oznacza to, że spośród 136 etatów 23,5\% przeznaczonych zostało na etaty obsługi, natomiast etatów dla pracowników merytorycznych (zajmujących się realizacją zadań RPP) ma być jedynie 40,4\%. Będą oni zajmować się, obok promowania mediacji między podatnikami a organami podatkowymi, współdziałania ze stowarzyszeniami i samorządami zawodowymi i ruchami obywatelskimi (krajowymi i międzynarodowymi), prowadzenia działalności edukacyjnej i informacyjnej dotyczącej prawa podatkowego, również przedstawianiem organom, organizacjom lub instytucjom publicznym wniosków zmierzających do zapewnienia ochrony praw podatnika, wzmocnienia spójności prawa podatkowego, usunięcia zbędnych procedur czy wymogów formalnych lub usprawnienia załatwiania spraw, analizą sposobu załatwiania przez organy podatkowe skarg i wniosków, opiniowaniem projektów aktów normatywnych z zakresu prawa podatkowego, analizą orzecznictwa sądów administracyjnych $\mathrm{w}$ sprawach podatkowych oraz orzecznictwa innych sądów $\mathrm{i}$ trybunałów $\mathrm{w}$ zakresie, $\mathrm{w}$ jakim wpływają na rozstrzyganie spraw podatkowych, analizą interpretacji ogólnych oraz interpretacji indywidualnych, 
wydawanych na podstawie przepisów Ordynacji podatkowej (art. 13 projektu). W tym kontekście warto zauważyć, że w obecnej kadencji Sejmu złożono ok. 120 projektów ustaw podatkowych, a więc takich, których główną materią są zagadnienia podatkowe, w kadencji VII takich projektów było 86, w VI - $132^{29}$, w 2018 r. wydano ok. 23,5 tys. interpretacji indywidualnych, zaś rok wcześniej ok. 27,2 tys. ${ }^{30}$, w 2016 r. do wojewódzkich sądów administracyjnych wpłynęło prawie 21 tys. skarg na decyzje organów podatkowych, a do Naczelnego Sądu Administracyjnego prawie 7 tys. skarg kasacyjnych). Liczba zakładanych etatów merytorycznych jest wiec niewspółmierna do zakresu zadań i kompetencji Rzecznika.

Projektowana ustawa może rodzić pozytywne skutki społeczne wynikające z troski organów państwa o zagwarantowanie praw podatnikom i zwiększenie ich poczucia bezpieczeństwa w kontaktach z organami administracji skarbowej.

Ustawa będzie rodzić skutki finansowe dla sektora finansów publicznych, których efektem będzie wzrost dochodów i wydatków (odpowiednio o $83 \mathrm{mln}$ zł i o 263 mln zł w okresie 10-letnim) skutkujący ujemnym saldem w kwocie $179 \mathrm{mln}$ zł (zob. s. 5 i n. OSR).

\section{Podsumowanie - ogólna ocena projektu}

Reasumując, należy stwierdzić, że analiza przedłożonego projektu i jego uzasadnienia, porównanie zadań i liczby przewidzianych etatów, organizacji aparatu wykonawczego Rzecznika wynikającej z projektu, przyjętej formuły wyłaniania RPP, jego finansowania, zakresu kompetencji skłonić może do postawienia tezy, że skuteczność RPP uzależniona będzie w praktyce od jego aktywności w wykonywaniu ustawowych zadań. Istotne będą także jego relacje ustrojowe i faktyczne z ministrem właściwym do spraw finansów publicznych i organami podatkowymi oraz podjęcie przez właściwe organy działań mających na celu poprawę efektywności zarządzania daninami publicznymi, a więc realizacji funkcji programowania, planowania, projektowania i tworzenia prawa daninowego oraz zarządzania poborem danin publicznych.

Zob. wykaz projektów ustaw na www.sejm.gov.pl.

30 Zob. informację o wykonaniu budżetu ministra właściwego do spraw budżetu, finansów publicznych i instytucji finansowych w 2018 r., część 19, Ministerstwo Finansów, Warszawa, czerwiec 2019 r., s. 41. 